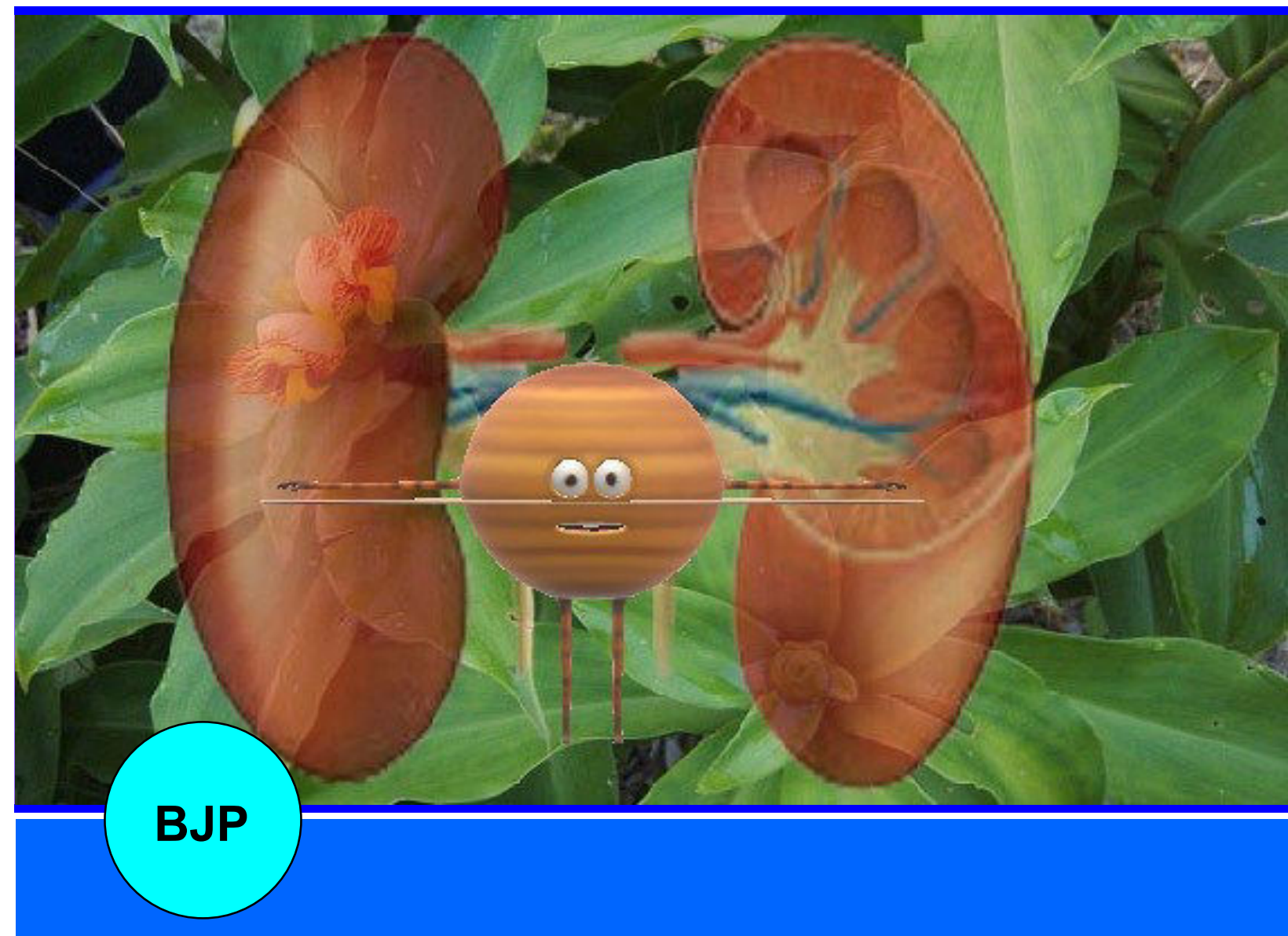

Bangladesh Journal of Pharmacology

Research Article

Nephroprotective effect of Costus pictus extract against doxorubicininduced toxicity on Wistar rat 


\section{Nephroprotective effect of Costus pictus extract against doxorubicin -induced toxicity on Wistar rat}

\section{Muthiah Rajasekaran}

\section{School of Chemical and Biotechnology, SASTRA University, Thanjavur 613401, Tamil Nadu, India.}

\begin{tabular}{|c|c|}
\hline \multicolumn{2}{|l|}{ Article Info } \\
\hline Received: & 25 January 2019 \\
\hline Accepted: & 10 April 2019 \\
\hline Available Online: & 14 May 2019 \\
\hline \multicolumn{2}{|c|}{ DOI: 10.3329/bjp.v14i2.39992 } \\
\hline \multicolumn{2}{|c|}{$\begin{array}{l}\text { Cite this article: } \\
\text { Rajasekaran M. Nephroprotective } \\
\text { effect of Costus pictus extract against } \\
\text { doxorubicin-induced toxicity on } \\
\text { Wistar rat. Bangladesh J Pharmacol. } \\
\text { 2019; } 14 \text { : 93-100. }\end{array}$} \\
\hline
\end{tabular}

\begin{abstract}
The present study was conducted to evaluate the nephroprotective effect of a medicinal herb Costus pictus against doxorubicin-induced toxicity. Rats were divided into six groups and treated with doxorubicin and ethanol extract of the C. pictus. Doxorubicin was administered intraperitoneally with a single dose $(4 \mathrm{mg} / \mathrm{kg}$ ) per week for three weeks. The extract (200 or $400 \mathrm{mg} / \mathrm{kg}$ ) was administered orally for 4 weeks to two doxorubicin groups. Significant changes of the serum kidney markers, albumin, urea, uric acid and creatinine, and glutathione peroxidase, glutathione-S-transferase, catalase, superoxide dismutase, reduced glutathione and lipid peroxides in the kidney of doxorubicin-treated rat were observed. Histological features were also severely affected. However, biochemical and histological changes in the extract-treated rat were non-significant, showing that the herb is nephroprotective. The effects were comparable to the anti-oxidant vitamin $\mathrm{E}$.
\end{abstract}

\section{Introduction}

Doxorubicin, an anthracycline glycosidic antibiotic is one of the commonly used anti-cancer drugs against a variety of malignancies such as sarcomas, carcinomas and hematological cancers (Young et al., 1981). However, due to its severe toxicity to non-tumor organs such as the heart, kidney and liver (Silber and Barber, 1995), its use as a therapeutic agent has been limited. Though the heart is the major target of doxorubicininduced toxicity, concern has been expressed over the adverse effects on kidney. The kidney is an important site for xenobiotic metabolism and major eliminating pathways for antineoplastic drugs and their metabolites (Cummings and Schnellmann, 2013). Due to high rate of blood supply, about $25 \%$ of cardiac output and delayed drug excretion, the kidney is more prone to renal impairment (Lameire, 2014) during chemotherapy.

Toxicity of doxorubicin has been attributed to excess generation of free radicals and oxidative stress. Doxorubicin reduction to semiquinone radicals and formation of iron anthracycline complexes are highly reactive to membrane lipids, proteins and DNA, which ultimately cause severe nephrotoxicity (Saad et al., 2001). Doxorubicin also causes an imbalance between free radicals and endogenous anti-oxidants, resulting in injury to membrane and cellular components (Balli et al., 2004).

Administration of chemotherapeutic agents with antioxidant action or supplementing with natural antioxidants may augment the efficacy of chemotherapeutics (Rashid et al., 2013) besides reducing the oxidative stress damages. Plants such as Allium cepa (Pradeep and Srinivasan, 2018), Allium sativum (Anusuya et al., 2013), Berberis baluchistanica (Pervez et al., 2018), Berberis lyceum (Anwar et al., 2018), Cestrum nocturnum (Saleem et al., 2017), Curcuma longa (Sharma et al., 2006), Mentha piperita (Ullah et al., 2014), Olea europaea (Al-Attar and Alsalmi et al., 2017), Petroselinum crispum (Combest et al., 2005), Punica granatum, and Trigonella foenum-graecum (Pradeep and Srinivasan, 2018) are nephroprotective.

In the present study, Costus pictus a popular medicinal 
herb with rich anti-oxidants has been selected to assess the anti-oxidant mediated nephroprotective effect against doxorubicin toxicity. C. pictus, also known as spiral ginger and insulin plant, has been reported to have anti-oxidant activity (Jayasri et al., 2009) and is also used as infusion in renal disorders (MeléndezCamargo et al., 2006). It is also a rich source of ascorbic acid, alpha-tocopheral, beta-carotene, terpepenoids, steroids, and flavonoids (Shankarappa et al., 2011). C. pictus is also reported to have anti-cancer activity against colon and lung cancer cells (Sathuvan et al., 2012).

\section{Materials and Methods}

\section{Preparation of extract}

C. pictus leaves collected from the SASTRA University herbal garden were shade dried. The dried leaves were pulverized to coarse powder and extracted with ethanol using soxhlet apparatus. The extract was concentrated using rotary vacuum evaporator and stored. The plant was identified and authenticated in the Centre for Advanced Research in Indian System of Medicine, SASTRA University, Thanjavur. A voucher specimen

\section{Box 1: Histopathology techniques}

\section{Principle}

Good quality sections of tissue (human/animal) in either spontaneous or induced diseases to examine the change(s) using a light microscope

\section{Requirements}

Automatic slide stainer, automatic tissue processor (Carism/ $\mathrm{EQP} / \mathrm{CAF} 002)$, glass slide, hot plate, isopropyl alcohol, kidney tissue, paraplast wax, rotary microtome, slide holder, slide rack, tissue cassette, warm water tub, xylene

\section{Procedure}

Step 1 (Tissue fixation): Kidney tissue was fixed in formaldehyde buffer. Trimming the kidney to get and proper orientation. Trimmed kidney tissues were placed in tissue cassette for dehydration and wax infiltration.

Step 2 (Dehydration, cleaning and wax infiltration): Tissue jar was fitted with the processor and time was set. Dehydration with increasing concentration of isopropyl alcohol $(70,80,90$, 96 and $100 \%$ ) each for an hour. Cleaning alcohol with xylene twice. Wax infiltration with paraplast wax for an hour.

Step 3 (Embedding tissue in wax): Wax infiltrated tissue was removed from tissue jar and plastic tissue cassatte for embedding in wax.

Step 4 (Metal base mold was filled with molten wax): Kidney tissue was embedded inside the wax in proper orientation. The cassatte was placed on the metal mold before cooling wax which serve as the base of the block for sectioning. was submitted for future reference (CARISM-102/ SATRA).

\section{Chemicals}

Doxorubicin, with a commercial name Oncodox was purchased from the Cipla Ltd, India. Crest Biosystems diagnostic kits were purchased from the Diagnostic Suppliers Goa, India. All other reagents used were of analytical grades purchased from the Himedia Laboratories Ltd, India.

\section{Experimental animals}

Male Wistar rats ( Rattus norvegicus) with body weight between 150 and $200 \mathrm{~g}$ were procured from the Central Animal Facility, SASTRA University. The rats were fed with standard rodent feed and water ad libitum. About 30 healthy rats were divided into 5 groups with 6 rats each. Group I was control, administered with vehicle (ground nut oil). Group II was administered with doxorubicin (4 $\mathrm{mg} / \mathrm{kg} /$ week for three weeks i.p.). Group III received doxorubicin $(4 \mathrm{mg} / \mathrm{kg} /$ week for three weeks i.p.) and C. pictus extract $200 \mathrm{mg} / \mathrm{kg}$ was administered daily for four weeks orally. Group IV was administered with doxorubicin $(4 \mathrm{mg} / \mathrm{kg} /$ week. for three weeks i.p.) and C. pictus extract $(400 \mathrm{mg} / \mathrm{kg})$ daily
Tissue block was removed from the metal mold and cooled on ice plate.

Wax blocks were trimmed for sectioning

Step 5 (Sectioning): Tissue block was fixed in the rotary microtome and cut the sections. Rotate the microtome at normal speed for ribbon formation. Thickness of the tissue section was set at $6 \mu \mathrm{m}$. Tissue ribbon was placed on warm water tub for spreading. Pick up the section on the slide carefully. Label the slide and dry in a slide rack.

Fix the section on the slide by warming on a hot plate.

Step 6 (Staining): Slide was placed in a slide holder for staining with hematoxylene and eosin.

Step 7 (Dewaxing and rehydration): a) Dewaxing using xylene, b) rehydration of the section in ethanol in decreasing concentrations (100, 90, 80, 70 and distilled water), c) hematoxyline, d) distilled water, e) eosin, f) water, g) dehydration using increasing concentration of ethanol $(80,90$ and $100 \%)$, h) xylene rinsing

Step 8 (Cover slip mounting): Wipe the surface under the slide while keeping the tissue section covered with the clearing agent. Apply two drops of mounting medium (e.g. Eukitt). Place a cover slip on the slide and avoid the formation of bubbles.

Step 9 (Observation):

Step 10 ((photography):

\section{Reference}

Pervez et al., 2018; Zaware et al., 2018 
orally for four weeks. Group V was administered with doxorubicin ( $4 \mathrm{mg} / \mathrm{kg} /$ week for three weeks i.p.) and vitamin E (200 mg/kg daily orally for four weeks). After 4 weeks of treatment period, rats were anesthetized by $\mathrm{CO}_{2}$ asphyxiation and blood samples were collected by retro-orbital bleeding for serum separation. Kidneys were excised carefully after biopsy, washed with cold physiological saline and frozen for biochemical studies.

\section{Biochemical studies}

Kidney function markers albumin, urea, uric acid and creatinine were estimated in serum using Crest Biosystems diagnostic kits in a UV-Visual spectrophotometer. Kidney tissue homogenate was prepared in $0.1 \mathrm{M}$ Tris-HCL buffer and used for the estimation of lipid peroxidation, reduced glutathione, glutathione peroxidase, glutathione-S-transferase, catalase and superoxide dismutase.

Lipid peroxidation end product malondialdehyde was measured as an index for lipid peroxidation (Ohkawa et al., 1979) and expressed as $n$ moles of malondialdehyde released/mg of protein. The reduced glutathione content was measured following Ellman method (1959) and expressed the amount of glutathione as $\mu \mathrm{g} / \mathrm{mg}$ protein. Superoxide dismutase was measured as specific activity of the enzyme required for $50 \%$ inhibition of nitro blue tetrazolium and expressed as $\mu$ moles/min/ mg of protein (Kakkar et al., 1984). Catalase activity was determined by decomposition of $\mathrm{H}_{2} \mathrm{O}_{2}$ and expressed as $\mu$ moles of $\mathrm{H}_{2} \mathrm{O}_{2}$ decomposed/min/mg of protein (Aebi, 1974). Glutathione peroxidase was measured following Rotruck et al. (1973) method and expressed as $\mu \mathrm{mol}$ of glutathione consumed/mg of protein. Glutathione-Stransferase activity was measured as the catalytic reaction of 1-chloro-2,4-dinitrobenzene (CDNB) with reduced glutathione. (Habig et al., 1974). The enzyme activity is defined as the amount of enzyme required to convert $1 \mu \mathrm{mol}$ of substrate CDNB in 1 min per $\mathrm{mL}$ reaction mixture under assay condition $(\mu \mathrm{mol} / \mathrm{min} /$ $\mathrm{mL})$.

\section{Statistical analysis}

Statistical analysis of the results was done by one-way analysis of variance (ANOVA) using GraphPad prism 5 software, followed by Dunnet's comparison test for significance.

\section{Results}

The present study revealed significant alterations of kidney function markers in doxorubicin-treated groups (Table I). Serum albumin level was significantly $(p<0.05)$ reduced in rats treated with doxorubicin when compared to control group rats. On the other hand, serum urea, uric acid and creatinine levels were significantly $(p<0.05)$ increased by doxorubicin-treatment. However, the levels of albumin in both the C. pictus extract-treated groups were only moderately altered without significant variation from the control levels. Similarly, serum levels of urea, uric acid and creatinine in the extract-treated rats were found to be close to the control levels, without significant alterations. The levels of serum albumin, urea, uric acid and creatinine in both dose levels (200 and $400 \mathrm{mg} / \mathrm{kg}$ ) of C. pictus extract were comparable to the levels observed in vitamin $\mathrm{E}$ treated groups.

Doxorubicin administration also resulted in drastic alterations of kidney tissue anti-oxidants (Table II). Significant $(p<0.05)$ elevation of lipid peroxidation end product malondialdehyde was observed in doxorubicin group, indicating enhanced free radical mediated lipid peroxidation. On the other hand, extract-treated groups exhibited no significant changes of malondialdehyde content when compared to the control level, and was comparable to the vitamin E group, showing protective effect of the extract. The reduced glutathione, a nonenzymatic anti-oxidant was significantly lowered in the doxorubicin-treated groups. The reduced glutathione reduction was accompanied by significant $(p<0.05)$ reduction of kidney anti-oxidant enzymes glutathione-S -transferase, glutathione peroxidase, catalase and superoxide dismutase in the doxorubicin-treated groups when compared to control group rats. CPE treatment, however, showed significant protection against doxorubicin toxicity as evident from non-significant change of anti-oxidant enzymes when compared to the control

Table I

Serum markers of kidney function in different treatment groups

\begin{tabular}{|lrrrr|}
\hline Experimental groups & $\begin{array}{r}\text { Albumin } \\
(\mathrm{g} / \mathrm{dL})\end{array}$ & $\begin{array}{r}\text { Urea } \\
(\mathrm{U} / \mathrm{L})\end{array}$ & $\begin{array}{r}\text { Uric acid } \\
(\mathrm{mg} / \mathrm{dL})\end{array}$ & $\begin{array}{r}\text { Creatinine } \\
(\mathrm{mg} / \mathrm{dL})\end{array}$ \\
\hline Control & $4.2 \pm 0.1$ & $42.6 \pm 0.8$ & $2.3 \pm 0.3$ & $1.4 \pm 0.6$ \\
Doxorubicin & $2.3 \pm 0.1^{\mathrm{a}}$ & $58.9 \pm 0.3^{\mathrm{a}}$ & $7.7 \pm 0.1^{\mathrm{a}}$ & $3.8 \pm 0.7^{\mathrm{a}}$ \\
Doxorubicin + C. pictus extract $(200 \mathrm{mg} / \mathrm{kg})$ & $3.6 \pm 0.2^{\mathrm{b}}$ & $46.3 \pm 0.8^{\mathrm{b}}$ & $4.1 \pm 0.2^{\mathrm{b}}$ & $2.2 \pm 0.5$ \\
Doxorubicin + C. pictus extract $(400 \mathrm{mg} / \mathrm{kg})$ & $3.8 \pm 0.2$ & $44.1 \pm 0.2$ & $3.1 \pm 0.4$ & $1.1 \pm 0.3$ \\
Doxorubicin + Vitamin E $(200 \mathrm{mg} / \mathrm{kg})$ & $3.4 \pm 0.1 \mathrm{~b}$ & $43.3 \pm 0.9$ & $3.8 \pm 0.7 \mathrm{~b}$ & $0.8 \pm 0.1$ \\
Data are mean \pm SE of six observations; Significant from control values at ap<0.01; b $<<0.05$ & & & \\
\hline
\end{tabular}


Table II

Shows the level of lipid peroxides, glutathione and anti-oxidant enzymes in the kidney

\begin{tabular}{|c|c|c|c|c|c|c|}
\hline Treatment groups & $\begin{array}{l}\text { Lipid pe- } \\
\text { roxidation }\end{array}$ & $\begin{array}{l}\text { Reduced } \\
\text { glutathione }\end{array}$ & $\begin{array}{l}\text { Glutathione } \\
\text { peroxidase }\end{array}$ & $\begin{array}{l}\text { Glutathione- } \\
\text { S-transferase }\end{array}$ & Catalase & $\begin{array}{l}\text { Superoxide } \\
\text { dismutase }\end{array}$ \\
\hline Control & $16.6 \pm 1.5$ & $26.1 \pm 1.4$ & $19.0 \pm 1.2$ & $7.2 \pm 1.0$ & $18.0 \pm 1.8$ & $26.0 \pm 1.8$ \\
\hline Doxorubicin & $38.0 \pm 2.0^{\mathrm{a}}$ & $14.7 \pm 1.8^{\mathrm{a}}$ & $9.0 \pm 1.8^{a}$ & $2.5 \pm 1.6^{b}$ & $7.4 \pm 1.4^{a}$ & $12.1 \pm 1.4^{\mathrm{a}}$ \\
\hline Doxorubicin + C. pictus extract $(200 \mathrm{mg} / \mathrm{kg})$ & $21.5 \pm 1.5$ & $18.2 \pm 1.3^{\mathrm{b}}$ & $12.1 \pm 1.0^{\mathrm{b}}$ & $5.3 \pm 1.3$ & $11.9 \pm 1.8^{\mathrm{b}}$ & $18.7 \pm 1.5^{\mathrm{b}}$ \\
\hline Doxorubicin + C. pictus extract $(400 \mathrm{mg} / \mathrm{kg})$ & $19.7 \pm 1.2$ & $21.2 \pm 1.6$ & $17.6 \pm 1.6$ & $6.7 \pm 1.5$ & $16.1 \pm 1.1$ & $22.7 \pm 1.2$ \\
\hline Doxorubicin + Vitamin E $(200 \mathrm{mg} / \mathrm{kg})$ & $17.2 \pm 1.0$ & $23.6 \pm 1.4$ & $16.3 \pm 1.1$ & $6.4 \pm 0.6$ & $14.2 \pm 1.0$ & $21.3 \pm 1.9$ \\
\hline
\end{tabular}

group and vitamin E groups.

\section{Histological observations}

Histological observation of the kidney exhibited normal architecture in control rats. Glomerulus and Bowman's capsule appeared normal among the proximal and distal convoluted tubules. Proximal tubules are with columnar cells with deeply stained acidophilic cytoplasm. Distal tubules are shorter and narrower and lined with low cuboidal cells with less acidophilic cytoplasm with a central nucleus. Tubules are interspersed with minute capillaries.

Kidney of doxorubicin group rats were extensively damaged by doxorubicin. The kidney exhibited increased glomerular space, congestion of Bowman's capsule, tubular cell degeneration and vacuolation. Desquamation of epithelial cells and pyknotic nuclei were also noted. Localized mononuclear cell infiltration was also noted. Collecting tubules showed extensive cytoplasmic vacuolation and degeneration. Rats administered with CPE showed only mild degeneration of kidney tubular cells and glomerular congestion. Vitamin E treated group rats exhibited mild focal necrosis of the tubular cells. In general, histological observations of the of the CPE groups showed only mild alterations, indicating protection by the herb C. pictus (Figure 1).

\section{Discussion}

Kidney, a complex and dynamic organ helps elimination of wastes, regulates total homeostasis, and controls acid base balance (Perazella, 2009). Toxicological insult to kidneys would affect any or all of these functions. The observations of the present study substantiate these facts that kidney is more vulnerable to doxorubicin generated free radicals. Doxorubicin administration to rats caused significant reduction of serum albumin and elevations of urea, uric acid and creatinine when compared to the control levels. Plasma proteins include a heterogeneous group with albumin constituting the major portion. Though albumin is manufactured in the liver, when the kidneys are damaged they become leaky, allowing albumin to be excreted in the urine. This causes reduced serum concentration. Elevations of serum urea, uric acid and creatinine show poor clearance by kidney indicating doxorubicin-induced damage to the renal tissues. Doxorubicin-induced reduction of serum albumin, and increased uric acid ,urea and creatinine have been reported (Monsour et al., 1999). The levels of serum albumin, urea, uric acid and creatinine in the CPE treated groups were found to be not affected significantly. This shows that herbal compounds of C. pictus offered considerable protection to the kidney tissues. Similar nephroprotective effect of herbal plants against gentamicin toxicity have been reported (Pervez et al., 2018).

In addition to the changes of the renal function markers, anti-oxidant status of the kidneys in doxorubicin treated rats was drastically altered. Significantly elevated lipid peroxidation end products malondialdehyde in doxorubicin group of rats indicates accelerated lipid peroxidation by the free radicals. This can be attributed to doxorubicin caused free radical formation, oxidative damages of biological molecules, membrane lipid peroxidation and protein oxidation (Liu et al., 2007). Significant reduction in the levels of reduced glutathione and, anti-oxidant enzymes glutathione peroxidase, glutathione S-transferase, superoxide dismutase and catalase in the doxorubicin group rats indicate severe free radical mediated nephrotoxicity.

The reduced glutathione is the major non-enzymatic anti-oxidant for regulating intra cellular radical concentration (Chanson et al., 2007). The reduced glutathione scavenges hydroxyl radical and singlet oxygen directly, detoxifying hydrogen peroxides and lipid peroxides by the catalytic action of glutathione peroxidase. Glutathione is also a co-factor of detoxifying enzymes of oxidative stress such as glutathione peroxidase and glutathione-S-transferase. Glutathione-S 


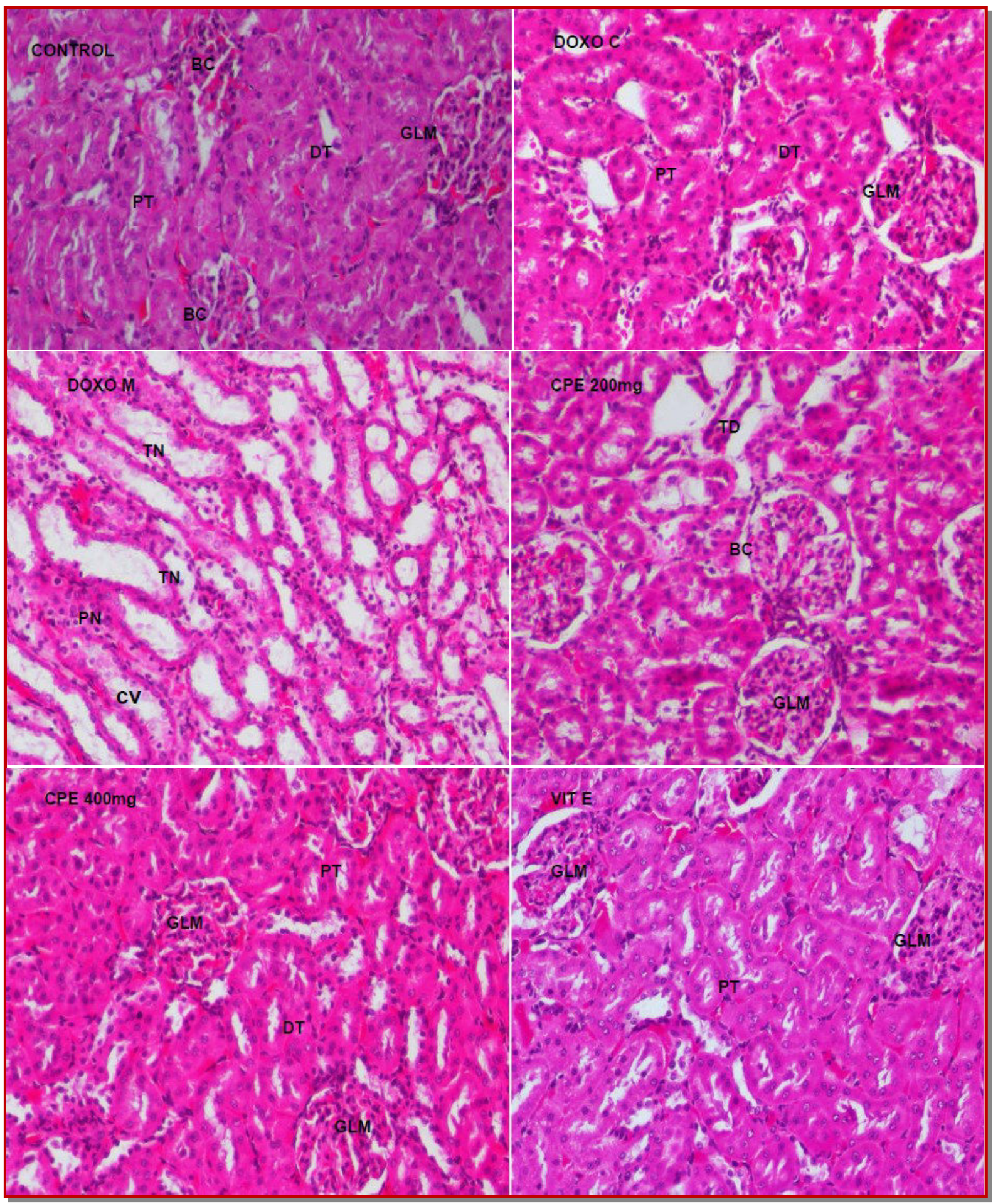

Figure 1: Shows the histological changes observed in the kidney of rats in the different treatment groups

CONTROL: The kidney shows normal architecture with intact glomerulus (GLM) and Bowman's capsule (BC). Proxiaml tubules (PT) and Distal tubules (DT) appear normal with tubular cells intact. Nuclei of the tubular cells are normal. DOXO C: Glomerular congestion, increased Bowman's space, tubular necrosis and lymphocytic infiltration were noted in the cortical region. DOXO M: Medullary region shows tubular degeneration (TD), cytoplasmic vacuolation (CV) and pyknotic nuclei (PN). CPE200 mg: Mild to moderate degeneration of the tubular cells. Glomerular congestion is mild. CPE $400 \mathrm{mg}$ : Glomerulus appear normal with reduced space. Proximal and distal tubules exhibit normal histology. Mild tubular degeneration at focal areas is noted.VIT E: Glomerulus and Bowman's capsule appear normal. Tubular cells are normal. Mild focal necris of the tubular cells is evident. 
-transferase exerts protection by catalyzing the conjugation of reduced glutathione with oxidation end products and defends against the highly toxic spectrum of substances produced by ROS. Both glutathione peroxidase and glutathione-S-transferase activities can eventually reduce the level of intracellular reduced glutathione (Masella et al., 2005). Reduction in the reduced glutathione level may also be due to reduced glutathione consumption in the interaction of doxorubicininduced free radicals with biomembranes and lipid peroxides. Reduced glutathione deficiency could be the possible reason for increased lipid peroxidation and reduction of glutathione peroxidase and glutathione-Stransferase (Elberry et al., 2010).

Anti-oxidant enzymes superoxide dismutase is the major enzyme acting against superoxide radicals, and catalase, and glutathione peroxidase catalyzes dismutation of superoxide anion into hydrogen peroxide, and converting $\mathrm{H}_{2} \mathrm{O}_{2}$ into water providing protection against ROS (Vasquez-Garzon et al., 2009). The reduction of anti-oxidant enzymes observed in the present study can be explained on the basis of their exhaustion in combating the oxidative stress caused by the doxorubicin-induced free radicals. The observations of the study shows that CPE treatment prevented lipid peroxidation, associated with normalization of the reduced glutathione and anti-oxidant enzymes, indicating that the plant has significant anti-peroxidation and anti-oxidant activities.

The biochemical changes observed in doxorubicintreated rats were well corroborated with the histological changes noted in the kidney. The damages observed in the kidney following doxorubicin treatment could be attributed to increased free radicals associated with diminished anti-oxidant enzymes that culminate to loss of cell membrane integrity and function. The possible reasons for the altered kidney markers and anti-oxidant enzymes might be due to epithelial cell damages and hemodynamic changes in glomeruli caused by doxorubicin (Mohajeri and Sahebkar, 2018).

Mild histological alterations associated with nonsignificant changes in the level of biochemical markers and anti-oxidant enzymes in the extract-treated group rats are indications of protection by the anti-oxidant compounds in C. pictus. Doxorubicin caused glomerular and tubular damages were protected by madecassoside triterpenoid of Centalla asiatica herb (Su et al., 2015). Normalization of the renal function markers and antioxidant enzymes by Murraya konigii in cyclophosphamide induced renal toxicity (Mahipal and Pawar, 2017) and Psidium guajava on doxorubicin-induced nephrotoxicity (Mohan et al., 2014) reveal that plants are effective in protecting kidney from the adverse effect of anti-cancer drugs. Protective activity of Eclipta prostrata against gentamicin nephrotoxicity has been attributed to its phytochemicals and anti-oxidant acti- vity (Ahmad et al., 2018). Nephroprotective activity of the plants is attributed to the diverse phytochemicals with multiple functions (Sundararajan et al., 2014). Review by Javaid et al. (2012) also showed that the antioxidant herbal drugs were effective for renal disorders. All these substantiate that herbs are promising sources of nephroprotective compounds. The protective effect of C. pictus extract against the doxorubicin caused nephrotoxicity can be attributed to the rich phytochemicals, particularly anti-oxidant compounds. This plant with its nephroprotective and anti-cancer effects can be used as preventive medicine against the adverse effects of chemotherapeutic agents.

\section{Conclusion}

Ethanol extract of $C$. pictus herb is effective in protecting kidney from free radical mediated doxorubicin toxicity.

\section{Ethical Issue}

Rats were procured from the Central Animal Facility, SASTRA University and maintained in an optimum condition as per the guidelines of Committee for the Purpose of Control and Supervision of Experiments on Animals. The study was approved by the institutions ethical committee(CPCSEA:149/ SASTRA/IAEC/RAP).

\section{Conflict of Interest}

Authors declare no conflict of interest.

\section{Acknowledgement}

The author wishes to thank the Dean, School of Chemical and Biotechnology, SASTRA University and the management for the facilities.

\section{References}

Aebi H. Catalase. In: Methods of enzymatic analysis. Bergmeyer HU, (eds). New York, Academic Press, 1974, pp 67377.

Ahmad F, Al-Subaie AM, Al-Ohalai AI, Mohammed AS. Phyto -chemical and nephroprotective activity of Eclipta prostrata against gentamicin-induced nephrotoxicity in Wistar rats. Int J Pharma Res Health Sci. 2018; 6: 2559-64.

Al-Attar AM, Alsalmi FA. Effect of Olea europaea leaves extract on streptozotocin-induced diabetes in male albino rats. Saudi J Biol Sci. 2017; 2017.

Anusuya N, Durgadevi P, Dhinek A, Mythily S. Nephroprotective effect of ethanolic extract of garlic (Allium sativum) on cisplatin induced nephrotoxicity in male Wistar Rats. Asian J Pharm Clin Res. 2013; 6(Suppl 4): 97-100. 
Anwar R, Sultan R, Batool F. Ameliorating effect of Berberis lycium root bark extracts against cisplatin-induced nephropathy in rat. Bangladesh J Pharmacol. 2018; 13: 248-54.

Balli E, Mete UO, Tuli A, Tap O, Kaya M. Effect of melatonin on the cardiotoxicity of doxorubicin. Histol Histopathol. 2004; 19: 1101-08.

Chanson A, Rock E, Martin JF, Liotard A, Brachet P. Preferential response of glutathione-related enzymes to folatae dependent changes in the redox state of rat liver. Eur J Nutr. 2007; 46: 204-12.

Combest W, Newton M, Combest A, Kosier JH. Effects of herbal supplements on the kidney. Urol Nurs. 2005; 25: 381-86.

Cummings BS, Schnellmann RG. Pathophysiology of nephrotoxic cell injury. In: Schrier's Diseases of the kidney. Coffman TM, Falk RJ, Molitoris BA, (eds). Philadelphia, Wolters Kluwer/Lippincott, Williams \& Wilkins, 2013, pp 868-900.

Elberry AA, Abdel-Naim AB, Abdel-Sattar EA, Nagy AA Mosli HA, Mohamadin AA, Ashour OM. Cranberry (Vaccinium macrocarpon) protects against doxorubicin-induced cardiotoxicity in rats. Food Chem Toxicol. 2010; 48: 1178-84.

Ellman GL. Tissue sulfhydryl groups. Arch Biochem Biophys. 1959; 82: 70-77.

Habig WH, Pabst MJ, Jacoby WB. Glutathione S-transferase, the first enzymatic step in mercapturic acid formation. J Biol Chem. 1974; 249: 7130-39.

Javaid R, Aslam M, Nizami Q, Javaid R. Role of anti-oxidant herbal drugs in renal disorders: An overview. Free Rad Antiox. 2012; 2: 2-5.

Jayasri MA, Mathew L, Radha A. A report on the anti-oxidant activity of leaves and rhizomes of Costus pictus D. Don. Int J Integr Biol. 2009; 5: 20-26.

Kakkar P, Das B, Viswanathan PN. A modified spectrophotometric assay of superoxide dismutase. Indian J Biochem Biophys. 1984; 21: 130-32.

Lameire N. Nephrotoxicity of recent anti-cancer agents. Clin Kidney. 2014; 7: 11-22.

Liu LL, Li QX, Xia L, Li J, Shao L. Differential effects of dihydropyridine calcium antagonists on doxorubicin-induced nephrotoxicity in rats. Toxicology 2007; 231: 81-90.

Mahipal P, Pawar RS. Nephroprotective effect of Murraya koenigii on cyclophosphamide induced nephrotoxicity in rats. Asian Pac J Trop Med. 2017; 10: 808-12.

Mansour MA, El-Kashef HA, Al-Shabanah OA. Effect of captopril on doxorubicin-induced nephrotoxixicity in normal rats. Pharmacol Res. 1999; 39: 233-37.

Masella R, Di Benedetto R, Vari R, Filesi C, Giovannini C. Novel mechanisms of natural anti-oxidant compounds in biological systems: Involvement of glutathione and glutathione related enzymes. J Nutr Biochem. 2005; 16: 577-86.

Meléndez-Camargo ME, Castillo-Nájera R, Silva-Torres R, Campos-Aldrete ME. Evaluation of the diuretic effect of the aqueous extract of Costus pictus D. Don in rat. Proc West Pharmacol Soc. 2006; 49: 72-74.

Mohajeri M, Sahebkar A. Protective effects of curcumin against doxorubicin-induced toxicity and resistance: A review. Crit Rev Oncol Hematol. 2018; 122: 30-51.

Mohan M, Shashank B, Vishnu Priya A. Protective effect of Psidium guajava L. leaves ethanolic extract on doxorubicininduced nephrotoxicity in rats. Indian J Nat Prod Resour. 2014; 5: 129-33.

Ohkawa H, Ohishi N, Yagi K. Assay for lipid peroxidation in animal tissues by thiobarbituric acid reaction. Anal Biochem. 1979; 95: 351-58.

Perazella MA. Renal vulnerability to drug toxicity. Clin J Am Soc Nephrol. 2009; 4: 1275-83.

Pervez S, Saeed M, Khan H, Shahid M, Ullah I. Nephroprotective effect of Berberis baluchistanica against gentamicininduced nephrotoxicity in rabbit. Bangladesh J Pharmacol. 2018; 13: 222-30.

Pradeep SR, Srinivasan K. Alleviation of oxidative stressmediated nephropathy by dietary fenugreek (Trigonella foenum-graecum) seeds and onion (Allium cepa) in streptozotocin-induced diabetic rats. Food Funct. 2018; 9: 13448.

Rashid S, Ali N, Nafees S, Ahmad ST, Arjumand W, Hasan SK, Sultana S. Alleviation of doxorubicin-induced nephrotoxicity and hepatotoxicity by chrysin in Wistar rats. Toxicol Mech Methods. 2013; 23: 337-45.

Rotruck JT, Pope AL, Ganther HE, Swanson AB, Hafeman DG, Hoekstra WG. Selenium: Biochemical role as a component of glutathione peroxidase. Science 1973; 179: 588-90.

Saad SY, Najjar TA, Al-Rikabi AC. The preventive role of deferoxamine against acute doxorubicin-induced cardiac, renal and hepatic toxicity in rats. Pharmacol Res. 2001; 43: 211-18.

Saleem U, Ali N, Ahmad B. Protective and curative effects of Cestrum nocturnum on rabbit kidney. Bangladesh J Pharmacol. 2017; 12: 284-91.

Sathuvan M, Vignesh A, Thangam R, Palani P, Rengasamy R, Murugesan K. In vitro anti-oxidant and anti-cancer potential of bark of Costus pictus D.DON. Asian Pac J Trop Biomed. 2012; 2: S741-49.

Shankarappa L, Gopalakrishna B, Jagadish NR, Siddalingappa GS. Pharmacognostic and phytochemical analysis of Costus ignitius. Internationale Pharmaceutica Sciencia. 2011; 1: 36-41.

Sharma S, Kulkarni SK, Chopra K. Curcumin, the active principle of turmeric (Curcuma longa), ameliorates diabetic nephropathy in rats. Clin Exp Pharmacol Physiol. 2006; 33: 940-45.

Silber JH, Barber G. Doxorubicin-induced cardiotoxicity. N Engl J Med. 1995; 333: 1359-60.

Su Z, Ye J, Qin Z, Ding X. Protective effects of madecassoside against doxorubicin induced nephrotoxicity in vivo and in vitro. Sci Rep. 2015; 5: 18314

Sundararajan R, Bhrampuram A, Koduru R. A review on phytoconstituents for nephroprotective activity. Phramacophore 2014; 5: 160-82.

Ullah N, Khan MA, Khan T, Asif AH, Ahmad W. Mentha piperita in nephrotoxicity: A possible intervention to ame- 
liorate renal derangements associated with gentamicin. Indian Young RC, Ozols RF, Myers CE. The anthracycline antiJ Pharmacol. 2014; 46: 166. neoplastic drugs. N Engl J Med. 1981; 305: 139-53.

Vasquez-Garzon VR, Arellanes-Robledo J, Garcia-Roman R, Zaware B, Gilhotra R, Chaudhari S. Potential of Mimosa pudica Aparicio-Rautista DI, Villa-Trevino S. Inhibition of reactive oxygen species and pre-neoplastic lesions by quercetin leaf in the treatment of ulcerative colitis in rat. Bangladesh J through an anti-oxidant defense mechanism. Free Radic Res. Pharmacol. 2018; 13: 241-47. 2009; 43: 128-37.

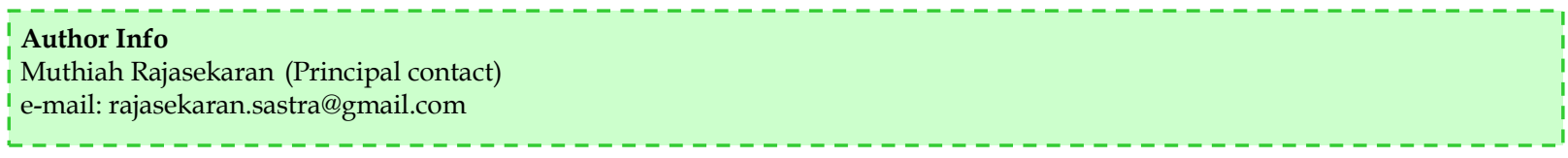

